\title{
PELATIHAN DAN PENYULUHAN PENGELOLAAN ALOKASI DANA DESA (ADD)
}

\author{
Muhammad Rinaldy Bima ${ }^{1}$, Muhammad Kamal ${ }^{2}$, Hardianto Djanggih ${ }^{3}$ \\ ${ }^{1}$ Fakultas Hukum Universitas Muslim Indonesia, \\ email: muhrinaldy.bima@umi.ac.id \\ ${ }^{2}$ Fakultas Hukum Universitas Muslim Indonesia \\ email: kamal.hidjaz@yahoo.co.id \\ ${ }^{3}$ Fakultas Hukum Universitas Muslim Indonesia \\ korespondensi email: hardianto.djanggih@umi.ac.id
}

\begin{abstract}
The problem of village fund management in 2015 and until 2018, the budget of village funds from the central government to South Sulawesi has reached a total of Rp.5.7 trillion spread over 2,255 villages. With that much budget, it should be a trigger for the performance of village officials to increase development as mandated by Law Number 6 of 2014 concerning Villages (Village Law. But in its development, the abundant village funds were prone to be misused. Based on ICW monitoring since from 2015 to 2018, cases of corruption in village funds have increased from year to year and there have been at least 181 cases of corruption in village funds with 184 suspects of corruption and a loss of Rp. 40.6 billion. Increasing abuse of village funds has also occurred in South Sulawesi, namely 22 cases have been recorded with state losses of 3.4 billion, so it is deemed necessary to take efforts through preemptive and preventive patterns so that misuse of village funds is not repeated in various regions, particularly in Baji Mangngai Village, Mandai District, Maros Regency. we make a legal study, as it is believed that jurisprudence ha dir in an effort to provide legal problem solving.
\end{abstract}

Keywords: counseling \& training; village fund allocation; corruption

\begin{abstract}
ABSTRAK
Permasalahan pengelolaan dana desa 2015 lalu hingga tahun 2018, anggaran dana desa dari pemerintah pusat ke Sulawesi Selatan totalnya telah mencapai Rp.5,7 triliun yang tersebar di 2.255 desa. Dengan anggaran sebanyak itu, maka seharusnya menjadi pemacu kinerja aparat desa untuk meningkatkan pembangunan sebagaimana diamanatkan pada MUndang-Undang Nomor 6 Tahun 2014 tentang Desa (UU Desa. Namun dalam perkembangannya, dana desa yang berlimpah tersebut ternyata rawan untuk disalahgunakan. Berdasarkan hasil pemantauan ICW sejak tahun 2015 hingga 2018, kasus korupsi dana desa mengalami peningkatan dari tahun ke tahun dan tercatat sedikitnya sudah ada 181 kasus korupsi dana desa dengan 184 tersangka korupsi dan nilai kerugian sebesar Rp 40,6 Miliar. Peningkatan penyalahgunaan dana desa juga terjadi di Sulawesi Selatan, yakni tercatat 22 kasus dengan kerugian negara sebesar 3,4 Milyar. Dengan demikian, dianggap perlu ada upaya melalui pola preemtif dan preventif agar penyalahgunaan dana desa tidak terulang kembali di berbagai wilayah, khususnya di Desa Baji Mangngai, Kecamatan
\end{abstract}


Mandai, Kabupaten Maros. Olehnya itu, kami membuat kajian hukum, sebagaimana diyakini bahwa ilmu hukum hadir dalam upaya memberikan legal problem solving.

Kata Kunci: penyuluhan \& pelatihan; alokasi dana desa; korupsi

\section{PENDAHULUAN}

Kabupaten Maros terdiri dari 14 (empat belas) kecamatan yang membawahi 103 Desa/kelurahan, dengan luas wilayah 1.619,12 km2. Kabupaten Maros merupakan wilayah yang sebelah Utara berbatasan dengan Kabupaten Pangkep, sebelah Timur berbatasan dengan Kabupaten Gowa dan Bone, sebelah Selatan berbatasan dengan Kabupaten Gowa dan Kota Makassar, sebelah Barat berbatasan dengan Selat Makassar. Kabupaten Maros memegang peranan penting terhadap pembangunan Kota Makassar karena sebagai daerah perlintasan yang sekaligus sebagai pintu gerbang Kawasan Mamminasata bagian utara, yang memiliki sarana transportasi udara terbesar di kawasan Timur Indonesia, sehingga menjadi tempat masuk dan keluar dari dan ke Sulawesi Selatan. Tentu saja kondisi ini sangat menguntungkan perekonomian Maros secara keseluruhan.

Desa Baji Mangngai berada di Kecamatan Mandai, dimana Kecamatan Mandai dengan luas wilayah 49,11 $\mathrm{KM}^{2}$, terdiri dari 6 (enam) desa, yaitu: Desa Pattontongan dengan luas wilayah $11,47 \mathrm{KM}^{2}$, Baji Mangngai dengan luas wilayah 9,98 $\mathrm{KM}^{2}$, Tenrigangkae dengan luas wilayah $6,43 \mathrm{KM}^{2}$, Bonto Matene dengan luas wilayah $12,69 \mathrm{KM}^{2}$, Bontoa dengan luas wilayah 4,38 $\mathrm{KM}^{2}$, dan Hasanuddin dengan luas wilayah $4,11 \mathrm{KM}^{2}$.

Desa adalah desa dan desa adat atau yang disebut dengan nama lain, selanjutnya disebut Desa, adalah kesatuan masyarakat hukum yang memiliki batas wilayah yang berwenang untuk mengatur dan mengurus urusan pemerintahan, kepentingan masyarakat setempat berdasarkan prakarsa masyarakat, hak asal usul, dan/atau hak tradisional yang diakui dan dihormati dalam sistem pemerintahan Negara Kesatuan Republik Indonesia. ${ }^{1}$

Pembangunan Desa adalah upaya peningkatan kualitas hidup dan kehidupan untuk sebesarbesarnya kesejahteraan masyarakat Desa. Pembangunan dan pemberdayaan desa merupakan salah satu komitmen pemerintah untuk menghadirkan pemerataan ekonomi di Tanah Air. ${ }^{3}$ Orientasi pembangunan nasional beberapa tahun ini mengalami perubahan, yakni pembangunan dimulai dari desa. Kenaikan alokasi anggaran untuk pembangunan desa setiap tahunnya menjadi salah satu indikasi pemerintah memprioritaskan desa sebagai program utama pembangunan. Program Dana Desa harus meningkatkan kesejahteraan masyarakat desa, seiring dengan

\footnotetext{
1 Sutrisno Purwohadi Mulyono (2014). Sinergitas Penyelenggaraan Pemerintahan Desa Pasca Pemberlakuan Uu No. 6 Tahun 2014 Tentang Desa. Masalah-Masalah Hukum, 43(3), hal:438.

2 Adang Danial, Yus Darusman, Mustakim \& Wiwin Herwina (2019). Model Pemberdayaan Masyarakat Melalui Pola Magang Tradisional Dalam Upaya Peningkatan Wirausaha Masyarakat. Jurnal Inovasi Hasil Pengabdian Masyarakat (JIPEMAS), 2(1), hal:42

${ }^{3}$ Coristya Berlian Ramadana, Heru Ribawanto, Suwondo, (2013). Keberadaan Badan Usaha Milik Desa (BUMDES) sebagai Penguatan Ekonomi Desa. Jurnal Administrasi Publik, 1(6), Hal: 1069
} 
meningkatnya perputaran uang di wilayah pedesaan. Semakin banyak perputaran uang yang ada di desa, kesejahteraan masyarakat desa akan meningkat pesat. ${ }^{4}$

Keuangan Desa adalah semua hak dan kewajiban Desa yang dapat dinilai dengan uang serta segala sesuatu berupa uang dan barang yang berhubungan dengan pelaksanaan hak dan kewajiban Desa. Pada 2015, tahun awal kebijakan Dana Desa dijalankan, pemerintah memberikan Dana Desa Rp. 20,7 triliun. Pada 2016 menjadi Rp. 47 triliun, pada 2017 sebesar Rp. 60 triliun, kemudian 2018 juga Rp. 60 triliun. Pada 2019, Dana Desa meningkat menjadi Rp73 triliun. Jadi sampai tahun ini sudah Rp187 triliun dana digelontorkan ke 74 ribu desa, yang ada di seluruh Tanah Air. ${ }^{5}$

Sejak 2015 hingga 2017 tercatat sejumlah infrastruktur dan fasilitas desa dibangun secara massif dari Dana Desa, yaitu sepanjang 123 ribu kilometer jalan desa, 11.500 posyandu, 18.100 PAUD, 6.500 pasar desa, hingga 791.000 meter jembatan berhasil dibangun dari dana desa yang disalurkan. Melihat capaian tersebut di sejumlah desa, infrastruktur jalan desa menjadi lebih baik dibanding sebelumnya dan dilengkapi dengan fasilitas penunjang lain seperti irigasi, embung, hingga fasilitas kesehatan seperti posyandu.

Gubernur Sulsel Nurdin Abdullah menyatakan alokasi anggaran dana desa dari pusat untuk daerahnya terus meningkat. Pada tahun 2018 nilainya Rp. 1,98 triliun, sedangkan dalam tiga tahun terakhir mencapai Rp. 5,7 triliun. Anggaran disebar ke 2.255 desa, di 24 kabupaten/kota. Dana Desa telah diperuntukkan untuk berbagai keperluan masyarakat, antara lain dibangun 7.164 kilometer jalan desa, jembatan, irigasi, embung, PAUD beragam program lain. Masyarakat Desa berharap agar Dana Desa bisa dilanjutkan dan ditingkatkan baik kualitas dan kuantitasnya, karena langsung dirasakan manfaatnya oleh masyarakat dengan menurunnya angka kemiskinan dan meningkatnya pendapatan masyarakat.

Program Dana Desa diharapkan dalam pelaksanaan selanjutnya mampu mengubah berbagai potensi desa menjadi kekuatan ekonomi. Selain infrastruktur, dana-dana itu bisa digunakan untuk membangun, misalnya pariwisata di desa, untuk mengembangkan sumber daya manusia dan penggarapan potensi desa, untuk meningkatkan kesehatan masyarakat di pedesaan, salah satunya dengan memanfaatkan Dana Desa untuk menanggulangi masalah gizi buruk dan stunting atau gagal tumbuh yang ada di desa-desa. ${ }^{6}$

Namun, kenyataan yang terjadi terkait Program Alokasi Dana Desa, tidak berjalan mulus sesuai dengan tujuannya yaitu meningkatkan

\footnotetext{
${ }^{4}$ Muhammad Ismail, Ari Kuncara Widagdo, Agus Widodo, (2016). Sistem Akuntansi Pengelolaan Dana Desa. Jurnal Ekonomi dan Bisnis, 19(2), Hal: 324

${ }^{5}$ Suci Indah Hanifah, Sugeng Praptoyo, Akuntabilitas dan Transparansi Pertanggungjawaban Anggaran Pendapatan Belanja Desa (APBDes). Jurnal IImu \& Riset Akuntansi, 4(8), Hal: 2

${ }^{6}$ Fajar Sidik, (2015). Menggali potensi lokal mewujudkan kemandirian Desa. JKAP (Jurnal Kebijakan dan Administrasi Publik), 19(2), Hal: 119
} 
pembangunan dan kesejahteraan masyarakat di Desa. ${ }^{7}$ Anti Corruption Committee (ACC) Sulawesi merilis data penanganan perkara tindak pidana korupsi (Tipikor) berdasarkan pelimpahan kasus dari kejaksaan ke pengadilan negeri (PN) Makassar. Salah satu kasus paling disoroti, yakni penyalahgunaan dana desa sebanyak 22 kasus dengan kerugian negara telah mencapai Rp. 3,4 miliar lebih. Kasus korupsi dana desa di Sulawesi Selatan mengalami peningkatan apabila dibandingkan dengan tahun 2017, hanya 11 kasus. $^{8}$

Dana desa rentan dikorupsi karena lemahnya pengawasan terhadap pengelolaan dana desa, kedua soal kesiapan desa dalam mengelola anggaran yang besar. Kemudian yang ketiga kurangnya transparansi pengelolaan dana

desa.

Dari seluruh kasus dana desa, jumlah kerugian negara mencapai kurang lebih Rp.3,4 miliar yang bersumber dari APBD lewat Alokasi Dana Desa (ADD) dan Dana Desa (DD) dari APBN. Adapun jumlah terdakwa pada kasus ini sebanyak 21 kepala desa ditambah enam terdakwa dari perangkat desa, termasuk tiga terdakwa dari kelompok tani/petani/kelompok masyarakat desa. Bahkan ada juga camat yang terlibat dengan modus meminta kepada kepala desa saat pembuatan laporan dan evaluasi program.

ACC Sulawesi mencatat, jumlah kasus dana desa di Sulawesi Selatan terbesar terjadi di Kabupaten Bone, disusul Kabupaten Luwu Timur, kemudian Sidrap dan, di Kabupaten Gowa. Salah satu kasus penyelewengan anggaran dana desa di Sulawesi Selatan terjadi di Desa Tinggimae, Kecamatan Barombong, Kabupaten Gowa yang melibatkan Kepala Desa (sekarang mantan), bersama dua bawahannya yakni Kepala Urusan Keuangan (KAUR$\mathrm{KU})$, dan Ketua Badan Pengawas Desa.

Dengan demikian, dianggap perlu ada upaya melalui pola preemtif dan preventif agar penyelewengan dana desa tidak terulang kembali di berbagai wilayah, khususnya di Desa Tinggimae, Kecamatan Barombong, Kabupaten Gowa. Olehnya itu, kami membuat kajian hukum, sebagaimana diyakini bahwa ilmu hukum hadir dalam upaya memberikan legal problem solving. Maka berangkat dari kegiatan pengabdian berjudul "Penyuluhan Hukum dan Pelatihan Pengelolaan Alokasi Dana Desa di Desa Tinggimae, Kabupaten Gowa" diharapkan mampu memberikan hasil kajian yang mampu mendeskripsikan bentuk ideal pengelolaan dana desa dimasa akan datang.

Mendasari uraian sebelumnya, program pengabdian masyarakat ini, menemukan beberapa hal yang menjadi permasalahan pada Mitra lokasi Pengabdian masyarakat, yaitu:

1. Masyarakat Desa berhak atas kesejahteraan, sehingga mencapai taraf kehidupan yang layak. Kesejahteraan dapat dicapai dengan

\footnotetext{
${ }^{7}$ Marten Bunga, Aan Aswari, \& Hardianto Djanggih, (2018). Konsepsi Penyelamatan Dana Desa Dari Perbuatan Korupsi. Halu Oleo Law Review, 2(2), Hal: 449

8 Syachrul Arsyad, ACC Sulawesi Sebut Kasus Korupsi Dana Desa Meningkat di Sulsel, https://makassar.sindonews.com/read/19260/1/acc-sulawesi-sebut-kasus-korupsi-dana-desa-meningkat-disulsel-1546876901
} 
pembangunan masyarakat desa yang harus dilakukan bersama antara perangkat desa dan seluruh masyarakat. Pelibatan masyarakat dalam pengelolaan anggaran dana desa, baik dari segi perencanaan maupun pelaksanaannya sangat menentukan peningkatan pembangunan di pedesaan.

2. Peningkatan pembangunan desa sangat ditentukan oleh kemampuan kepala desa dan seluruh perangkat desa dalam membuat perencanaan pengelolaan alokasi dana desa sesuai skala prioritas kebutuhan seluruh masyarakat desa dengan memperhatikan potensi-potensi yang ada di desa untuk meningkatkan kekuatan ekonomi.

3. Indikator keberhasilan pengelolaan alokasi dana desa, dapat dilihat dari kesesuaian antara perencanaan, pelaksanaan, pembuatan laporan, serta pengawasan dan evaluasi penggunaan dana desa. Alokasi Dana Desa bertujuan untuk meningkatkan kesejahteraan masyarakat desa. Penyalahgunaan dana desa dapat menghambat percepatan pembangunan di desa.

\section{METODE PELAKSANAAN}

Metode yang digunakan dalam pelatihan/penyuluhan adalah metode pelatihan partisipatif, yaitu melibatkan sebanyak mungkin peran serta mitra dalam kegiatan pembinaan perangkat desa dan masyarakat. Program pembinaan yang sudah disepakati dengan Mitra Binaan di Desa Baji Mangngai Kabupaten Maros dilakukan dengan metode sebagai berikut:

1. Perancangan perencanaan pengelolaan.

2. Pelatihan pelaksanaan pengelolaan.

3. Pelatihan pembuatan laporan.

4. Penyuluhan/pelatihan bagi perangkat desa dan masyarakat.

Untuk itu diperlukan rancangan yang meliputi pelaksanaan kegiatan dan evaluasi program. Adapun rancangan pelaksanaan kegiatan dan evaluasi program adalah sebagai berikut:

1. Rancangan Pelaksanaan kegiatan:

a. Persiapan kegiatan yang dilakukan mencakup:

- Koordinasi dengan stakeholder terkait: Mitra Binaan di Desa Tinggimae Kabupaten Gowa.

- Menentukan koordinator lapangan untuk memudahkan komunikasi selama kegiatan berlangsung.

- Persiapan dan penyusunan bahan/ modul/ materi pelatihan.

b. Pemberian pelatihan program pembinaan:

- Pendampingan/pelatihan program pembinaan yang harus dilakukan secara giat dan rutin seperti sosialisasi aturan hukum menyangkut pengelolaan alokasi dana desa.

- Pendampingan/pelatihan program pembinaan bersama pihak Mitra Binaan di Desa Baji Mangngai Kabupaten Maros dengan cara memberikan pemahaman dan mengajak masyarakat untuk ikut 
aktif melakukan pengawasan terhadap pengelolaan alokasi dana desa.

- Pendampingan pelatihan program pembinaan bersama pihak Mitra melalui penyuluhan dan sosialisasi aturan hukum dan sanksi bagi pelaku penyalahgunaan alokasi dana desa.

2. Evaluasi Kegiatan: setelah melaksanakan kegiatan training/pelatihan dari seluruh rangkaian program kegiatan, peserta akan dievaluasi:

- Pada akhir program pembinaan, seluruh peserta diharapkan memahami dan mengimplementasikan program pembinaan yang telah didapatkan dan dijelaskan pada pelatihan.

\section{HASIL DAN PEMBAHASAN}

\section{Susunan Tim Pelaksana}

Struktur panitia kegiatan dalam kegiatan ini tersusun oleh tim pelaksana (dua orang) dan dibantu oleh dua orang mahasiswa sebagai anggota teknis. Berikut merupakan susunan struktur pelaksanaan kegiatan pengabdian ini:

Tabel 1.

Struktur tim pelaksana

\begin{tabular}{ll}
\hline Ketua & Dr. Muhammad Rinaldy Bima, SH.,MH \\
Anggota & Dr. H. Muhammad Kamal, SH.,MH \\
\hline & \\
& Struktur Anggota Teknis \\
\hline Ketua & Muhammad Ya'rif Arifin, SH.,MH \\
Anggota & Hadeliana \\
\hline
\end{tabular}

\section{Bentuk Kegiatan, Waktu dan Tempat Kegiatan}

Kegiatan pengabdian ini telah dilaksanakan sesuai dengan jadwal dan rincian kegiatan yang telah ditetapkan dan disepakai sebelumnya. Berikut merupakan rangkaian waktu dan kegiatan yang telah dilakukan pada hari Rabu, 20 November 2019 di Desa Baji Mangngai, Kecamatan Mandai, Kabupaten Maros:

Tabel 2.

Jadwal Pelaksanaan Kegiatan

\begin{tabular}{cll}
\hline Waktu & \multicolumn{1}{c}{ Kegiatan } & \multicolumn{1}{c}{$\begin{array}{c}\text { Penanggung Jawab } \\
\text { Kegiatan }\end{array}$} \\
\hline $08.00-08.15$ & Registrasi peserta pelatihan & Muh Ya'rif Arifin, SH.,MH \\
$08.15-08.30$ & $\begin{array}{l}\text { Pembukaan oleh moderator } \\
\text { (Muh. Ya'rif Arifin, SH.,MH) }\end{array}$ & Tim pelaksana \\
& $\begin{array}{l}\text { Sambutan Kepala Desa Baji Mangngai } \\
\text { (Abdul Latif, S.Sos) }\end{array}$ & \\
$08.30-09.30$ & $\begin{array}{l}\text { Materi 1 - Perancangan Perencanaan } \\
\text { Pengelolaan }\end{array}$ & $\begin{array}{l}\text { Dr. Muhammad Rinaldy } \\
\text { Bima, SH.,MH }\end{array}$ \\
& &
\end{tabular}




\begin{tabular}{|c|c|c|}
\hline $09.30-10.30$ & $\begin{array}{l}\text { Materi } 2-\text { Pelatihan Pelaksanaan } \\
\text { Pengelolaan }\end{array}$ & $\begin{array}{l}\text { Dr. H. Muhammad Kamal, } \\
\text { SH.,MH }\end{array}$ \\
\hline $10.30-11.15$ & Materi 3 - Pelatihan Pembuatan Laporan & Abdul Latif, S. Sos \\
\hline $11.15-12.00$ & $\begin{array}{l}\text { Materi } 4 \text { - Penyuluhan/ Pelatihan Bagi } \\
\text { Perangkat Desa dan Masyarakat }\end{array}$ & $\begin{array}{l}\text { Baharuddin (Petugas P3MD } \\
\text { Kab. Maros) }\end{array}$ \\
\hline $13.00-15.00$ & Tanya Jawab & Tim pelaksana \\
\hline $15.00-16.30$ & Evaluasi Kegiatan & Tim Pelaksana \\
\hline $16.30-17.00$ & Penutupan & Tim pelaksana \\
\hline
\end{tabular}

\section{Peserta/ Partisipan Masyarakat Sasaran}

Kegiatan pengabdian ini diikuti oleh seluruh Perangkat Desa, Badan Permusyarawatan Desa, dan Tokoh-tokoh Masyarakat. Jumlah peserta hadir adalah 35 orang, yang terdiri dari Perangkat Desa (1 orang Kepala Desa, 1 orang Sekretaris Desa, 4 Orang Staf Desa), 5 orang dari Badan Permusyarawatan Desa, 11 orang Kepala Dusun Setempat dan 6 orang dari tokoh agama, dan 7 orang tokoh masyarakat.

Para peserta sangat antusias untuk mengikuti kegiatan ini, dibuktikan dengan kedatangan mereka yang tepat waktu walaupun dalam kondisi harus meninggalkan rutinitas dan pekerjaan sehari-hari. Antusiasme lainnya juga terlihat dalam mendengarkan penjelasan dari pemateri dan banyaknya pertanyaan yang diajukan seputar materi yang diberikan. Walaupun diakhir sesi kegiatan disediakan waktu khusus untuk tanya jawab, namun beberapa peserta juga mengajukan pertanyaan disela-sela materi yang diberikan.

Kegiatan pelatihan ini diawali dengan pembukaan oleh moderator dan diikuti pembacaan ayat suci Al-Quran (Do'a) oleh Muhammad Ya'rif Arifin, SH.,MH, merupakan Dosen Tetap Yayasan Wakaf UMI pada Fakultas IImu Hukum UMI.

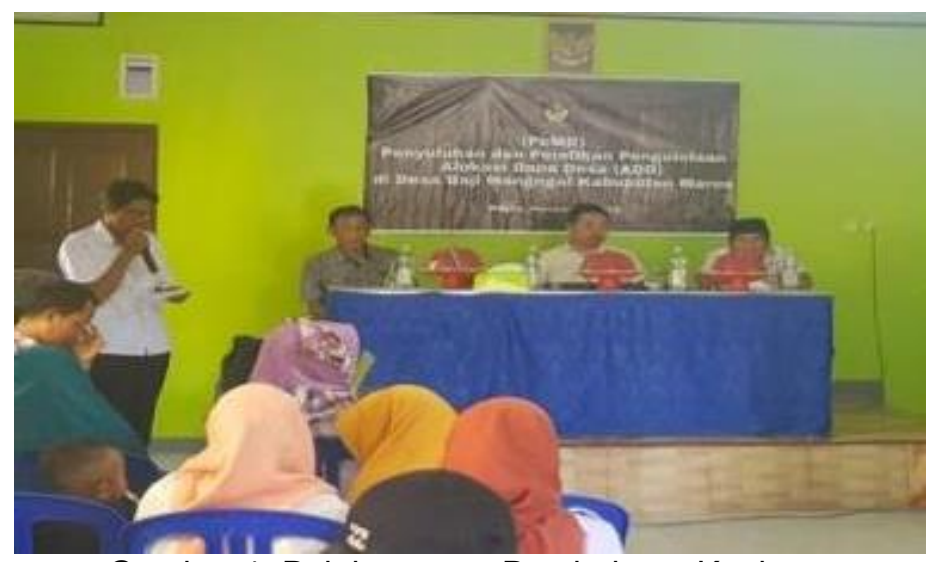

Gambar 1. Pelaksanaan Pembukaan Kegiatan 
Materi akan diberikan dalam empat sesi dan diakhiri dengan sesi Tanya jawab. Materi 1 adalah Perancangan Perencanaan Pengelolaan oleh Dr. Muhammad Rinaldy Bima, SH.,MH. Materi 2 adalah Pelatihan Pelaksanaan Pengelolaan oleh Dr. H. Muhammad Kamal, SH.,MH. Materi 3 adalah Pelatihan Pembuatan Laporan oleh Abdul Latif, S. Sos. Materi 4 adalah Penyuluhan/ Pelatihan Bagi Perangkat Desa dan Masyarakat oleh Baharuddin (Petugas P3MD Kab. Maros). Penutupan Kegiatan dengan melakukan Evaluasi Kegiatan dalam proses Pembinaan untuk mengetahui hasil dalam Pengabdian Kepada Masyarakat dan Dakwah.

\section{Tinjauan Hasil Yang Dicapai}

Pelaksanaan kegiatan PkMD dengan judul: "Penyuluhan Dan Pelatihan Pengelolaan Alokasi Dana Desa (ADD) Di Desa Baji Mangngai Kabupaten Maros" telah selesai dilaksanakan. Berikut merupakan hasil-hasil pada setiap tahapan kegiatan:

Tabel 3.

Kegiatan Pembinaan 1: Perancangan Perencanaan Pengelolaan

\section{Persiapan}

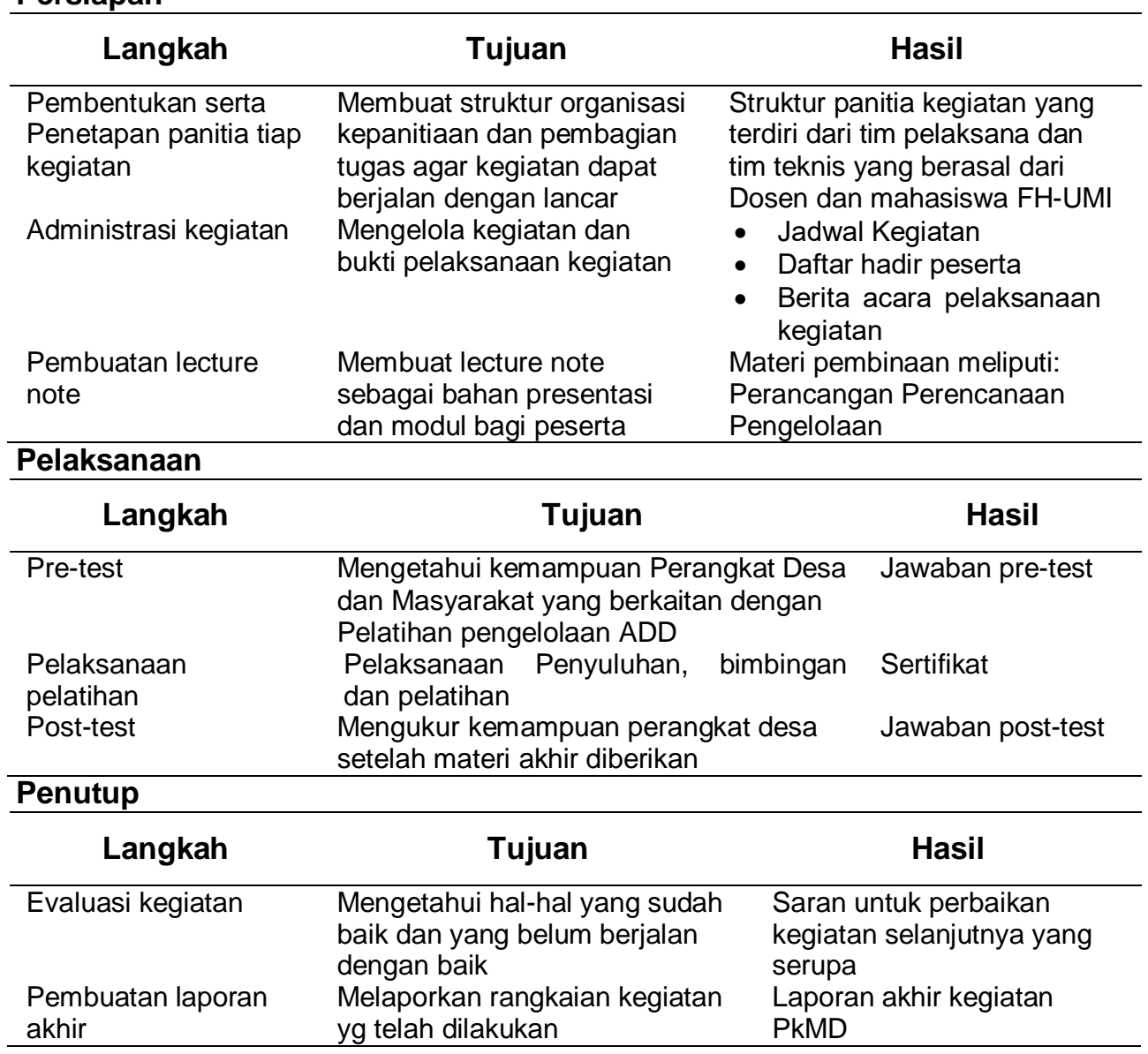




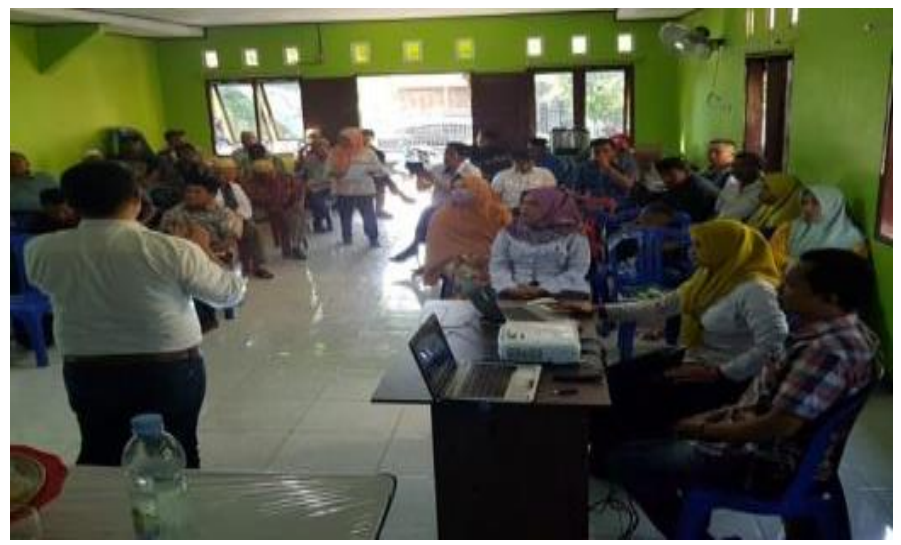

Gambar 2. Kegiatan Pembinaan 1

Tabel 4.

Persiapan

Kegiatan Pembinaan 2: Pelatihan Pelaksanaan Pengelolaan

Langkah

\begin{tabular}{ll}
\hline $\begin{array}{l}\text { Pembentukan serta } \\
\text { Penetapan panitia tiap } \\
\text { kegiatan }\end{array}$ & $\begin{array}{l}\text { Membuat struktur organisasi } \\
\text { kepanitiaan dan pembagian } \\
\text { tugas agar kegiatan dapat } \\
\text { berjalan dengan lancar }\end{array}$ \\
Administrasi kegiatan & $\begin{array}{l}\text { Mengelola kegiatan dan bukti } \\
\text { pelaksanaan kegiatan }\end{array}$ \\
$\begin{array}{l}\text { Pembuatan lecture } \\
\text { note }\end{array}$ & $\begin{array}{l}\text { Membuat lecture note sebagai } \\
\text { bahan presentasi dan modul } \\
\text { bagi peserta }\end{array}$ \\
$\begin{array}{l}\text { Pembuatan } \\
\text { pertanyaan pre-test } \\
\text { dan post-test }\end{array}$ & $\begin{array}{l}\text { Sebagai alat ukur kemampuan } \\
\text { peserta dalam memahami } \\
\text { materi yang diberikan }\end{array}$ \\
\hline
\end{tabular}

\section{Tujuan}

Hasil

Pelaksanaan

Langkah

Pre-test
Pelaksanaan pelatihan
Post-test

Tujuan

Hasil
Struktur panitia kegiatan yg terdiri dari tim pelaksana dan tim teknis yang berasal dari Dosen dan mahasiswa (anggota) FH- UMI

- Jadwal Kegiatan

- Daftar hadir peserta

- Berita acara pelaksanaan kegiatan

Materi pembinaan meliputi:

Pendekatan Minat dan

Motivasi Belajar

- Soal pre-test

- Soal post-test

\section{Penutup}

\section{Langkah}

Evaluasi kegiatan
Pembuatan laporan
akhir

Mengetahui kemampuan perangkat desa yang berkaitan dengan Pelatihan Pelaksanaan pelatihan Mengukur kemampuan perangkat desa setelah materi diberikan
Jawaban pre-test

Sertifikat

Jawaban post-test

\section{Tujuan}

Mengetahui hal-hal yang sudah baik dan yang belum berjalan dengan baik Melaporkan rangkaian kegiatan yang telah dilakukan
Hasil

Saran untuk perbaikan kegiatan selanjutnya yang serupa

Laporan akhir kegiatan PkMD 


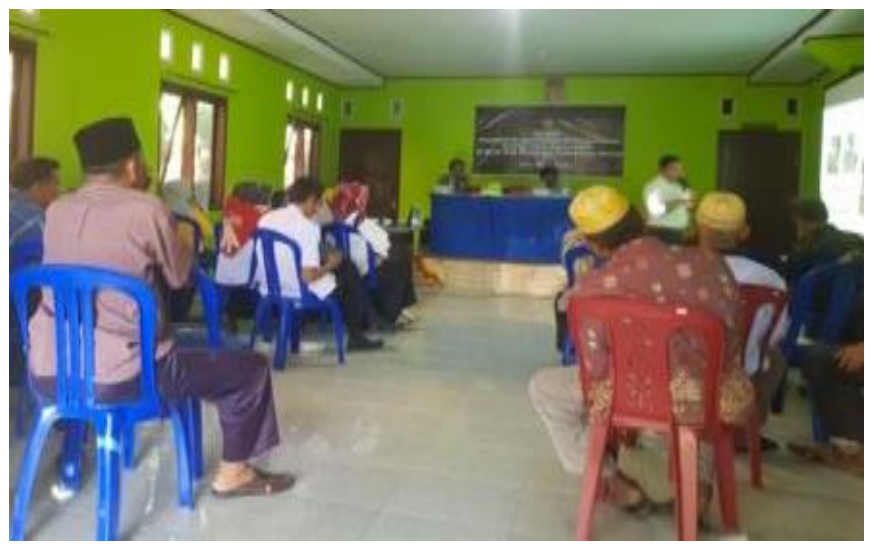

Gambar 3. Kegiatan Pembinaan 2

Tabel 5.

Persiapan

Kegiatan Pembinaan 3: Pelatihan Pembuatan Laporan

\section{Langkah}

Pembentukan serta
Penetapan panitia tiap
kegiatan

Administrasi kegiatan

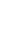
Mengelola kegiatan dan bukti
pelaksanaan kegiatan

\begin{tabular}{ll}
$\begin{array}{l}\text { Pembuatan lecture } \\
\text { note }\end{array}$ & $\begin{array}{l}\text { Membuat lecture note sebagai } \\
\text { bahan presentasi dan modul } \\
\text { bagi peserta }\end{array}$ \\
$\begin{array}{l}\text { Pembuatan } \\
\text { pertanyaan pre-test } \\
\text { dan post-test }\end{array}$ & $\begin{array}{l}\text { Sebagai alat ukur kemampuan } \\
\text { peserta dalam memahami } \\
\text { materi yang diberikan }\end{array}$ \\
\hline
\end{tabular}

Membuat struktur organisasi kepanitiaan dan pembagian tugas agar kegiatan dapat berjalan dengan lancar

Pelaksanaan

\section{Langkah}

Tujuan
Mengetahui kemampuan perangkat desa yang berkaitan dengan Pelatihan.

Pelaksanaan pelatihan Mengukur kemampuan Siswa setelah materi diberikan

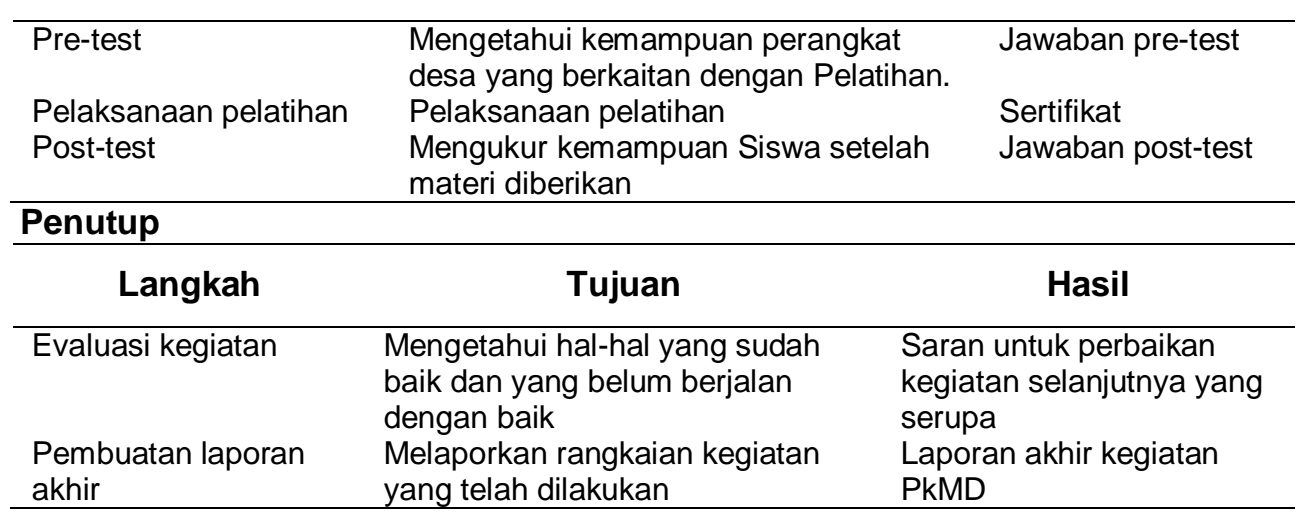

Hasil

Struktur panitia kegiatan yg terdiri dari tim pelaksana dan tim teknis yang berasal dari Dosen dan mahasiswa (anggota) FH- UMI

- Jadwal Kegiatan

- Daftar hadir peserta

- Berita acara pelaksanaan kegiatan Materi pembinaan, meliputi: Pembinaan Minat dan Bakat Siswa

- Soal pre-test

- Soal post-test akhir yang telah dilakukan PkMD 


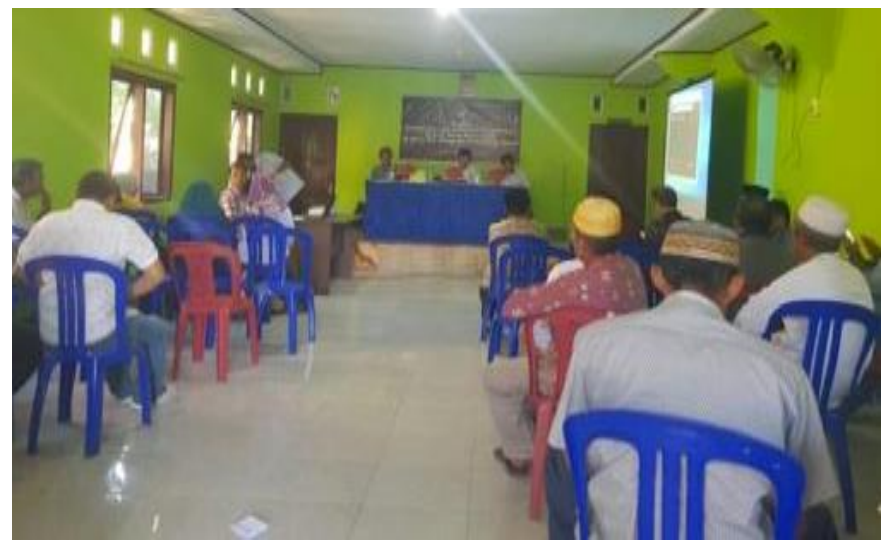

Gambar 4. Kegiatan Pembinaan 3

Tabel 6.

Kegiatan Pembinaan 4: Penyuluhan/ Pelatihan Bagi Perangkat Desa dan

Persiapan Masyarakat

\begin{tabular}{|c|c|c|c|}
\hline Langkah & Tujuan & & Hasil \\
\hline $\begin{array}{l}\text { Pembentukan serta } \\
\text { Penetapan panitia tiap } \\
\text { kegiatan }\end{array}$ & $\begin{array}{l}\text { Membuat struktur organisasi } \\
\text { kepanitiaan dan pembagian } \\
\text { tugas agar kegiatan dapat } \\
\text { berjalan dengan lancar }\end{array}$ & $\begin{array}{l}\text { Struktur } p \\
\text { terdiri dari } \\
\text { tim teknis } \\
\text { Dosen da } \\
\text { (anggota) }\end{array}$ & $\begin{array}{l}\text { nitia kegiatan yg } \\
\text { tim pelaksana dan } \\
\text { lang berasal dari } \\
\text { mahasiswa } \\
\text { =akultas Hukum UMI }\end{array}$ \\
\hline Administrasi kegiatan & $\begin{array}{l}\text { Mengelola kegiatan dan } \\
\text { bukti pelaksanaan kegiatan }\end{array}$ & $\begin{array}{l}\text { - Jadwa } \\
\text { - } \text { Daftar } \\
\text { - } \text { Berita } \\
\text { kegiat }\end{array}$ & $\begin{array}{l}\text { Kegiatan } \\
\text { hadir peserta } \\
\text { acara pelaksanaan } \\
\text { in }\end{array}$ \\
\hline $\begin{array}{l}\text { Pembuatan lecture } \\
\text { note }\end{array}$ & $\begin{array}{l}\text { Membuat lecture note } \\
\text { sebagai bahan presentasi } \\
\text { dan modul bagi peserta }\end{array}$ & $\begin{array}{l}\text { Materi per } \\
\text { Penyuluh } \\
\text { Perangka } \\
\text { Masyarak }\end{array}$ & $\begin{array}{l}\text { binaan meliputi: } \\
\text { n/ Pelatihan Bagi } \\
\text { Desa dan } \\
\text { t }\end{array}$ \\
\hline $\begin{array}{l}\text { Pembuatan } \\
\text { pertanyaan pre-test } \\
\text { dan post-test }\end{array}$ & $\begin{array}{l}\text { Sebagai alat ukur } \\
\text { kemampuan peserta dalam } \\
\text { memahami materi yang } \\
\text { diberikan }\end{array}$ & $\begin{array}{l}\text { - Soal p } \\
\text { - Soal p }\end{array}$ & $\begin{array}{l}\text { e-test } \\
\text { st-test }\end{array}$ \\
\hline \multicolumn{4}{|l|}{ Pelaksanaan } \\
\hline Langkah & Tujuan & & Hasil \\
\hline Pre-test & \multicolumn{2}{|c|}{$\begin{array}{l}\text { Mengetahui kemampuan } \\
\text { Perangkat desa yang berkaitan dengan } \\
\text { Pelatihan }\end{array}$} & Jawaban pre-test \\
\hline $\begin{array}{l}\text { Pelaksanaan pelatihan } \\
\text { Post-test }\end{array}$ & \multicolumn{2}{|c|}{$\begin{array}{l}\text { Pelaksanaan pelatihan } \\
\text { Mengukur kemampuan perangkat desa } \\
\text { setelah materi diberikan }\end{array}$} & $\begin{array}{l}\text { Sertifikat } \\
\text { Jawaban post-test }\end{array}$ \\
\hline
\end{tabular}


Penutup

\begin{tabular}{lll}
\hline \multicolumn{1}{c}{ Langkah } & \multicolumn{1}{c}{ Tujuan } & \multicolumn{1}{c}{ Hasil } \\
\hline Evaluasi kegiatan & $\begin{array}{l}\text { Mengetahui hal-hal yang sudah } \\
\text { baik dan yang belum berjalan } \\
\text { dengan baik }\end{array}$ & $\begin{array}{l}\text { Saran untuk perbaikan } \\
\text { kegiatan selanjutnya yang } \\
\text { serupa }\end{array}$ \\
$\begin{array}{ll}\text { Pembuatan laporan } \\
\text { akhir }\end{array}$ & $\begin{array}{l}\text { Melaporkan rangkaian kegiatan } \\
\text { yang telah dilakukan }\end{array}$ & $\begin{array}{l}\text { Laporan akhir kegiatan } \\
\text { PkMD }\end{array}$ \\
\hline
\end{tabular}

\section{Evaluasi Kegiatan}

Dalam kegiatan "Perancangan perencanaan pengelolaan" oleh panitia pelaksana mempersilahkan kepada pemateri yaitu oleh Dr. Muhammad Rinaldy Bima, SH.,MH. Kegiatan selanjutnya adalah proses tanya jawab yang berkaitan dengan permasalahan perancangan perencanaan pengelolaan Alokasi Dana Desa (ADD) yang dihadapi oleh peserta pelatihan. Hal ini bertujuan untuk memahami aturan tentang pengelolaan ADD. Selanjutnya menemukan kendala atas permasalahan dan bagaimana cara mencari solusi dalam menyelesaikan permasalahan tersebut. Setelah Tanya jawab selesai, pemateri memberikan post-test, untuk mengukur tingkat penerimaan dan pemahaman peserta selama mengikuti kegiatan pelatihan ini.

Dalam kegiatan "Pelatihan Pelaksanaan Pengelolaan" oleh panitia pelaksana mempersilahkan kepada pemateri yaitu oleh Dr. H. Muhammad Kamal, SH.,MH. Kegiatan selanjutnya adalah proses tanya jawab yang berkaitan dengan permasalahan pelaksanaan pengelolaan Alokasi Dana Desa (ADD) yang dihadapi oleh peserta pelatihan. Hal ini bertujuan untuk memahami aturan tentang pelaksanaan pengelolaan ADD. Selanjutnya menemukan kendala atas permasalahan dan bagaimana cara mencari solusi dalam menyelesaikan permasalahan tersebut. Setelah Tanya jawab selesai, pemateri memberikan post-test, untuk mengukur tingkat penerimaan dan pemahaman peserta selama mengikuti kegiatan pelatihan ini.

Dalam kegiatan "Pembuatan Laporan" oleh panitia pelaksana mempersilahkan kepada pemateri yaitu oleh Abdul Latif, S. Sos. Kegiatan selanjutnya adalah proses tanya jawab yang berkaitan dengan permasalahan pembuatan laporan pengelolaan Alokasi Dana Desa (ADD) yang dihadapi oleh peserta pelatihan. Hal ini bertujuan untuk memahami aturan tentang pelaksanaan pengelolaan ADD. Selanjutnya menemukan kendala atas permasalahan dan bagaimana cara mencari solusi dalam menyelesaikan permasalahan tersebut. Setelah Tanya jawab selesai, pemateri memberikan post-test, untuk mengukur tingkat penerimaan dan pemahaman peserta selama mengikuti kegiatan pelatihan ini.

Dalam kegiatan "Penyuluhan/ Pelatihan Bagi Perangkat Desa dan Masyarakat" oleh panitia pelaksana mempersilahkan kepada pemateri yaitu oleh Bapak Baharuddin (Penyuluh dari Pemerintah Daerah 
Kabupaten Maros). Kegiatan selanjutnya adalah proses tanya jawab yang berkaitan dengan permasalahan pengelolaan Alokasi Dana Desa (ADD) yang dihadapi oleh peserta pelatihan. Hal ini bertujuan untuk memahami aturan tentang pengelolaan ADD. Selanjutnya menemukan kendala atas permasalahan dan bagaimana cara mencari solusi dalam menyelesaikan permasalahan tersebut. Setelah Tanya jawab selesai, pemateri memberikan post-test, untuk mengukur tingkat penerimaan dan pemahaman peserta selama mengikuti kegiatan pelatihan ini.

Evaluasi Kegiatan: setelah melaksanakan kegiatan penyuluhan/pelatihan dari seluruh rangkaian program kegiatan, peserta akan dievaluasi: Pada akhir program pembinaan, seluruh peserta diharapkan memahami dan mengimplementasikan program yang telah didapatkan dan dijelaskan pada pelatihan.

\section{Permasalahan Dan Hambatan}

Setelah melaksanakan kegiatan penyuluhan dan pelatihan pengelolaan Alokasi dana Desa maka ditemukan berbagai permasalahan dan hambatan, sebagai berikut:

a. Kurangnya pengetahuan perangkat desa dan masyarakat desa mengenai pengelolaan Alokasi Dana Desa. Hal ini terlihat dari beberapa program kegiatan/pembangunan yang sudah disepakati dalam pertemuan perencanaan pengelolaan alokasi dana desa, namun tidak dapat terealisasikan atau dilaksanakan, seperti pembangunan rumah ibadah, dan lampu jalan desa. Bahkan kegiatan/pembangunan tersebut menjadi temuan oleh Inspektorat Kabupaten Maros. Menurut pemeriksa dari Inspektorat, bahwa pembangunan rumah ibadah tersebut tidak dapat dilaksanakan karena dibangun di atas tanah yang bukan milik desa. Demikian pula mengenai lampu jalan, bukan merupakan kewenangan desa, melainkan kewenangan Dinas Pekerjaan Umum. Hal ini untuk menghindari tumpang tindih anggaran.

b. Penggunaan Alokasi Dana Desa hanya digunakan untuk pembangunan infrastruktur desa, sedangkan dalam pembinaan/peningkatan sumber daya masyarakat desa sangat jarang dilakukan.

c. Kesesuaian antara perencanaan dan tujuan dana desa belum sesuai, karena tidak semua program alokasi dana desa terealisasi dengan baik. Hal ini diakibatkan kurangnya pengalaman dalam perencanaan kerja yang baik.

\section{KESIMPULAN}

Berdasarkan pembahasan, kegiatan pengabdian masyarakat ini ditarik kesimpulan sebagai berikut: Pertama, Kurangnya pengetahuan perangkat desa dan masyarakat desa mengenai pengelolaan Alokasi Dana Desa. 
Kedua, Penggunaan Alokasi Dana Desa hanya digunakan untuk pembangunan infrastruktur desa, sedangkan dalam pembinaan/peningkatan sumber daya masyarakat desa sangat jarang dilakukan. Ketiga, Kesesuaian antara perencanaan dan tujuan dana desa belum sesuai, karena tidak semua program alokasi dana desa terealisasi dengan baik. Hal ini diakibatkan kurangnya pengalaman dalam perencanaan kerja yang baik.

Adapun yang menjadi rekomendasi/saran dalam kegiatan pengabdian masyarakat ini adalah: Pertama, perlu dilakukan sosialisasi, penyuluhan dan pelatihan bagi perangkat desa dan masyarakat desa terkait pengelolaan Alokasi dana desa yang lebih intens. Kedua, perlu adanya dukungan Alokasi Dana Desa tidak hanya dipergunakan untuk pembangunan infrastruktur desa, tetapi juga diperuntukkan bagi pengembangan sumber daya masyarakat desa. Ketiga, perlu adanya Program pembangunan/kegiatan dalam penggunaan Alokasi Dana Desa harus lebih mengutamakan kebutuhan masyarakat desa dengan mempertimbangkan skala prioritas.

\section{DAFTAR RUJUKAN}

\section{Jurnal:}

Bunga, M., Aswari, A., \& Djanggih, H. (2018). Konsepsi Penyelamatan Dana Desa Dari Perbuatan Korupsi. Halu Oleo Law Review, 2(2), 448-459.

Danial, A., Darusman, Y., Mustakim, M., \& Herwina, W. (2019). Model Pemberdayaan Masyarakat Melalui Pola Magang Tradisional Dalam Upaya Peningkatan Wirausaha Masyarakat. Jurnal Inovasi Hasil Pengabdian Masyarakat (JIPEMAS), 2(1), 31-48.

Ismail, M., Widagdo, A. K., \& Widodo, A. (2016). Sistem Akuntansi Pengelolaan Dana Desa. Jurnal Ekonomi dan Bisnis, 19(2), 323-340.

Mulyono, S. P. (2014). Sinergitas Penyelenggaraan Pemerintahan Desa Pasca Pemberlakuan Uu No. 6 Tahun 2014 Tentang Desa. MasalahMasalah Hukum, 43(3), 438-444.

Hanifah, S. I., \& Praptoyo, S. (2015). Akuntabilitas dan Transparansi Pertanggungjawaban Anggaran Pendapatan Belanja Desa (APBDes). Jurnal Ilmu \& Riset Akuntansi, 4(8), 1-15.

Sidik, F. (2015). Menggali potensi lokal mewujudkan kemandirian Desa. JKAP (Jurnal Kebijakan dan Administrasi Publik), 19(2), 115-131.

Ramadana, C. B. (2013). Keberadaan Badan Usaha Milik Desa (BUMDES) sebagai Penguatan Ekonomi Desa. Jurnal Administrasi Publik, 1(6), 1068-1076.

\section{Sumber Lain:}

Syachrul Arsyad, ACC Sulawesi Sebut Kasus Korupsi Dana Desa Meningkat di Sulsel, https://makassar.sindonews.com/read/19260/1/acc-sulawesisebut-kasus-korupsi-dana-desa-meningkat-di-sulsel-1546876901

Perundang-Undangan:

Undang-Undang Nomor 6 Tahun 2014 tentang Desa (Lembaran Negara Republik Indonesia Tahun 2014 Nomor 7) 
Peraturan Menteri Dalam Negeri Nomor 20 Tahun 2018 Tentang Perubahan Pengelolaan Keuangan Desa.

Peraturan Pemerintah Nomor 43 Tahun 2014 tentang Peraturan Pelaksanaan Undang-Undang Nomor 6 tahun 2014 tentang, sebagaimana diubah terakhir dengan Peraturan Pemerintah Nomor 47 Tahun 2015 tentang Perubahan atas Peraturan Pemerintah Nomor 43 Tahun 2014 Tentang Peraturan Pelaksanaan Undang-Undang Nomor 6 Tahun 2014 tentang Desa

Peraturan Pemerintah Nomor 60 Tahun 2014 tentang Dana Desa yang Bersumber dari Anggaran Pendapatan dan Belanja Negara, sebagaimana telah diubah terakhir dengan Peraturan Pemerintah Nomor 8 Tahun 2016 tentang Perubahan Kedua atas Peraturan Pemerintah Nomor 60 Tahun 2014 tentang Dana Desa yang Bersumber dari Anggaran Pendapatan dan Belanja Negara 